\title{
Author Correction: Daphnia stressor database: Taking advantage of a decade of Daphnia '-omics' data for gene annotation
}

\author{
Suda Parimala Ravindran $\mathbb{D}$, Jennifer Lüneburg, Lisa Gottschlich, Verena Tams \& \\ Mathilde Cordellier (iD
}

Correction to: Scientific Reports https://doi.org/10.1038/s41598-019-47226-0, published online 31 July 2019

In the original version of this Article, Jennifer Lüneburg and Lisa Gottschlich were incorrectly affiliated with 'Universität Hamburg, Institut für marine Ökosystem- und Fischereiwissenschaften, Große Elbstraße 133, 22767 Hamburg, Germany'. In addition, Verena Tams was incorrectly affiliated with 'Universität Hamburg, Institute of Zoology, Martin-Luther-King Platz 3, 20146, Hamburg, Germany’.

The correct affiliations are listed below:

Affiliation 1:

Department of Marine Sciences, Tjärnö Marine Laboratory, University of Gothenburg, 45296 Strömstad, Sweden Suda Parimala Ravindran

Affiliation 2:

Universität Hamburg, Institute of Zoology, Martin-Luther-King Platz 3, 20146 Hamburg, Germany

Jennifer Lüneburg, Lisa Gottschlich, Mathilde Cordellier

Affiliation 3:

Universität Hamburg, Institut für marine Ökosystem- und Fischereiwissenschaften, Große Elbstraße 133, 22767 Hamburg, Germany

Verena Tams

This error has now been corrected in the PDF and HTML versions and Supplementary Information file which accompanies the Article.

(c) (i) Open Access This article is licensed under a Creative Commons Attribution 4.0 International (c) License, which permits use, sharing, adaptation, distribution and reproduction in any medium or format, as long as you give appropriate credit to the original author(s) and the source, provide a link to the Creative Commons license, and indicate if changes were made. The images or other third party material in this article are included in the article's Creative Commons license, unless indicated otherwise in a credit line to the material. If material is not included in the article's Creative Commons license and your intended use is not permitted by statutory regulation or exceeds the permitted use, you will need to obtain permission directly from the copyright holder. To view a copy of this license, visit http://creativecommons.org/licenses/by/4.0/.

(c) The Author(s) 2020 